The problem of removing heavy and radioactive metals from the human body is relevant all over the world. Recent research has shown that it is more effective to use substances contained in natural food products, including pectin. Pectin has a favorable effect not only under acute exposure to metals, but also with their prolonged entry into the body, which is typical for an environmental load of residents of industrial regions and modern megalopolis.

The use of pectin substances as natural detoxicants requires research to preserve these substances in products and further use. Therefore, an important condition for using pectin concentrates is to determine the shelf life for safe consumption. Based on this, studies were conducted to determine optimal storage parameters and terms for pumpkin concentrate.

The sequence and parameters of pectin concentrate production from Karina pumpkin pomace are justified.

As a result of the study, it was found that during storage of pectin concentrate from Karina pumpkin pomace at a temperature of $8{ }^{\circ} \mathrm{C}$ for 10 months, the pectin content in the concentrate decreased by $0-12.45 \%$, at $25{ }^{\circ} \mathrm{C}-$ by 0-63\%, compared to the control sample. Based on the results, it can be concluded that the safe storage period of pectin-containing concentrates from Karina pumpkin extracts at a temperature of $25^{\circ} \mathrm{C}$ is 7 months, at $8^{\circ} \mathrm{C}$ 10 months.

As a result of mathematical processing of experimental data, equations for the relationship of pectin amount with storage temperature, $\mathrm{pH}$ and time are obtained

Keywords: flow diagram, pectin concentrate, safe storage terms, pectin mass ratio, mathematical description

Received date 07.06.2021 Accepted date 22.07.2021 Published date 30.08.2021
口-

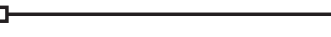

UDC 664.8.036

$10.15587 / 1729-4061.2021 .237940$

\section{JUSTIFICATION OF PECTIN CONCENTRATE SAFE STORAGE TERMS BY PECTIN MASS RATIO}

\author{
Galiya Iskakova \\ Corresponding author \\ Doctor of Technical Sciences, Associate Professor*
}

E-mail: iskakova-61@mail.ru

Maigu I Kizatova

Doctor of Technical Sciences, Professor

Department of Pharmaceutical Technology

Asfendiyarov Kazakh National Medical University

Tole bi str., 94, Almaty, Republic of Kazakhstan, 050012

Meruyet Baiysbayeva

$\mathrm{PhD}$, Associate Professor*

San avar Azimova

$\mathrm{PhD}$, Senior Lecturer**

Assel Izembayeva $\mathrm{PhD}$, Senior Lecturer*

Zhuldyz Zharylkassynova Master's Degree, Doctoral Student** *Department of Technology of Bakery Products and Processing Industries*** **Department of Food Safety and Quality*** ***Almaty Technological University Tole bi str., 100, Almaty, Republic of Kazakhstan, 050012

How to Cite: Iskakova, G., Kizatova, M., Baiysbayeva, M., Azimova, S., Izembayeva, A., Zharylkassynova, Z. (2021).
Justification of pectin concentrate safe storage terms by pectin mass ratio. Eastern-European Journal of Enterprise
Technologies, 4 (11 (112)), 25-32. doi: https://doi.org/10.15587/1729-4061.2021.237940

1. Introduction

The uniqueness of the physicochemical properties of pectin substances attracts increasing scientific attention. An active search is underway for substances that can protect the health of people working in harmful production, as well as residents of large industrial centers. Preference is given to detoxicants of natural origin, such as pectins $[1,2]$.

Pectin has many useful properties: it increases the body's allergic resistance, has a beneficial effect on cellular respiration of tissues and general metabolism, etc. [3-5]. Getting into the gastrointestinal tract, pectins form gels, swelling of which leads to dehydration of the digestive tract and, moving in the intestine, these gels capture toxic substances. Galacturonic acid formed during the hydrolytic decomposition of pectin under the action of intestinal microflora promotes detoxification of harmful substances.

One of the most important biologically active properties of pectin-containing products is the complexing ability, based on the interaction of pectin with heavy and radioactive metal ions. The complexing ability is the basis for designing food products based on pectin-containing raw materials. At the same time, low-esterified pectin substances, including pumpkin pectin, have the best complexing properties.

Thus, research on the quality and safe storage terms of pumpkin pectin concentrate opens up broad prospects for creating new safe food products with pronounced functional properties.

\section{Literature review and problem statement}

Environmental pollution with heavy metals is considered a serious threat to public health due to the toxicity of these pollutants and the lack of effective materials with metal-binding properties. Some biopolymers, such as pectins, have been proposed to remove metal ions from industrial drains. The chemical structure of pectins is very diverse and 
significantly affects their metal-binding properties. The influence of contact time, $\mathrm{pH}$ of the medium and equilibrium metal concentration on the metal binding process was tested in experiments. It is found that the min equilibrium time required for $\mathrm{Pb}$ (II) absorption by pectate compounds is 60 minutes. The results show that low molecular weight calcium pectate is a more promising means for removing $\mathrm{Pb}$ (II) ions from contaminated wastewater [6].

Pectins are soluble dietary fibers, biopolymers that are part of the cellular walls of plates and cytoplasm of plant cells. They are found in almost all fruits and vegetables. Being a tissue structural element, pectins provide integrity and stabilization of plant cell tissues, ensure water-salt metabolism, and are characterized by high gelling capacity. Pectins are essential in human nutrition as "dietary fiber" components, have a wide range of physiological activity [7, 8].

In [9], a search was made for the rational use of medicinal plants to obtain pectin substances. The relevance of this study is due to a significant deficit of most of the necessary biologically active substances, in particular pectin, in the population. In order to expand sources of raw materials of biologically active substances, non-conventional raw materials were studied, such as roots of greater burdock Arctium lappa L., common dandelion Taraxacum officiale Wigg. and elecampane Inula helenium L. These raw materials were chosen because, firstly, all of them are pharmacopoeial preparations, secondly, they have similar therapeutic properties and chemical composition. The obtained pectins were compared with conventional pectins and attributed to low-esterified pectins with the content of free carboxyl groups 3.0-3.8, esterified groups $2.4-3.7$, polyurethanes $57-64 \%$. Sorption properties of dandelion, burdock and elecampane pectins with respect to cadmium and copper ions have been studied.

Laboratory tests showed that pine and larch pectins make it possible to obtain viscous jellies that cannot be cut with a knife [10]. Such a jelly structure is allowed for candy centers formed by starch molding and fillings for shaped chocolate goods. Pectins from the bark of coniferous trees have an insufficiently high degree of esterification (46-48\%) and low molecular weight. The obtained pectins can be used as a jelling agent in confectionery only in the presence of calcium ions. Also, coniferous pectins can be successfully used in various fruit and berry semi-finished products for flour confectionery and pastries. Since all the studied coniferous pectins have a low degree of esterification, it is advisable to use them in preventive and therapeutic products with a high content of pectin substances and low sugar content.

Clinical trials were conducted to assess the sorption capacity of citrus pectin. A series of model whey solutions of salts of essential and toxic metals of different concentrations were prepared. The concentration of metals in the solution corresponded to $0.5 ; 1.0 ; 2.5 ; 3.5 ; 5.0 \mathrm{mg} / \mathrm{l}$. The sorbent-solution ratio was 1:10. At the same time, citrus pectin demonstrated high efficiency for all the studied metals, with a capacity range from $40 \mu \mathrm{g} / \mathrm{g}$ for cadmium up to $63 \mu \mathrm{g} / \mathrm{g}$ for lead [11].

Pectin attracts great interest of cancer biologists due to its participation in detoxification of metals/carcinogens and anticarcinogenic properties. In particular, [12] showed that citrus pectin (CP) and modified citrus pectin (MCP) play an important inhibitory role in metastasis, invasion, angiogenesis and survival of cancer cells. The interaction and inactivation of $\mathrm{CP}$ and $\mathrm{MCP}$ oncogenes in prostate, breast, liver, lung, and melanoma cancer suggest that $\mathrm{CP}$ and
MCP may play an important role in cancer chemotherapy and chemoprophylaxis. In this review, the authors focus on the biological function of pectin in relation to its properties, sources, structure, and its potential role in carcinogen detoxification and cancer suppression. Future research should focus on isolating bioactive pectin components that may be useful in the development of cancer drugs.

Modified citrus pectin has been found to significantly increase urinary lead excretion in adults [13] and is especially recommended for children as a safe and harmless chelator [14]. The main therapeutic effect of pectin is associated with the peculiarities of its chemical structure. The presence of chemically active free carboxyl groups, alcohol hydroxyls and polygalacturonic acid promote chelation. The formed chelates remove heavy metals and nuclides from the body. There is evidence in the literature that pectins increase the antioxidant activity of blood and liver tissues [15].

Gelling conditions determine the degree of esterification. So, pectins with a high degree of esterification (above $50 \%$ ) form a strong jelly, low-esterified pectins (less than $50 \%$ ) jelly in the presence of calcium ions [10]. The degree of pectin esterification was found to determine the immunopetentiating effect [16]. Clinical studies have proven no side effects when taking preparations. Pectin intended for the treatment of acute intestinal diseases has a distinct and persistent positive effect in intestinal dysbiosis.

Low-esterified pectin substances, including pumpkin pectin, have the best complexing properties. Pumpkin pectin is somewhat inferior in gelling capacity to apple and citrus pectins, while having much better complexing properties, which is extremely important for making therapeutic food products. In [17], the degree of esterification in pumpkin pectin concentrate was found to be $34.7 \%$, the complexing ability of pumpkin pectin $-290 \mathrm{mg} \mathrm{Pb}^{2+} / \mathrm{g}$. The resulting pumpkin pectin concentrate can increase the effectiveness of certain drugs, reduce their toxic effect on the body and eliminate some side effects.

Consumption of any food and pharmaceutical products requires studying safe storage terms. The literature review has shown insufficient research on the shelf life of pectins and pectin products (pectin-containing extracts and concentrates). However, there are studies on the strength of pectin gels and viscosity of pectin solutions at different temperatures $\left(4^{\circ} \mathrm{C}, 25^{\circ} \mathrm{C}, 40^{\circ} \mathrm{C}\right)$. Both gel viscosity $([\eta])$ and strength decrease with increasing storage time, which is more noticeable at high temperatures. Storage conditions of pectin, especially high temperature, affect depolymerization, but whether this will be harmful for its intended application will depend on the functional value of changes. Compared to the sample taken immediately after manufacture, the gel strength decreased by an average of $7-12 \%$ after 6 months of storage. This could be due to the decomposition of pectin compounds by acids present in the product and weakening of consistency [18].

[19] studied low-methoxyl pectins (LMP) obtained by $\mathrm{HCl}, \mathrm{NaOH}$ and $\mathrm{NH}_{3}$ deesterification. The studied pectins were stored with or without the addition of $\mathrm{Na}_{2} \mathrm{CO}_{3}$ as a buffer at room temperature $\left(25-30{ }^{\circ} \mathrm{C}\right)$ or exposed to various levels of relative humidity (r. h.) at $37^{\circ} \mathrm{C}$. Loss of gelling capacity was observed in all pectin samples.

Due to more pronounced radioprotective, detoxifying properties of low-esterified pectin compared to high-esterified pectin, it is necessary to develop rational modes for 
extracting low-esterified pectin substances from various plant materials.

Processors of plant raw materials tend to use new, more cost-effective technologies for creating pectin concentrates from cheap secondary raw materials. For example, production of pectin concentrates from the pomace of various fruits in juice production, from pulp obtained by processing sugar beet at sugar plants, from sunflower baskets after processing it into oil, etc. However, the preservation of liquid pectin products - extracts and concentrates with different pectin contents has not been studied. The literature covers more about the production of expensive dry pectin with a humidity of $6-8 \%$ and recommendations for its storage and use in various products. In this regard, the problem of pectin concentrates with the preservation of the main active substance, depending on the conditions and time of storage, has not yet been solved and requires modern research.

\section{The aim and objectives of the study}

The aim of the study is to justify safe storage terms for the developed pectin-containing concentrates from pumpkin pomace, ensuring the expediency of using them in therapeutic and preventive nutrition.

To achieve the aim, the following objectives were set:

- to develop a flow diagram for the production of pectin concentrate from Karina variety pumpkin;

- to investigate safe storage terms for pectin concentrate from pumpkin pomace;

- to determine the mutual influence of different storage conditions of pumpkin pectin concentrate using the methods of multifactor experimental design by pectin mass ratio.

\section{Materials and methods of the study}

The objects of the study are Karina pumpkin pomace, pumpkin pectin extract, pumpkin pectin concentrate.

Pectin content was determined by the method described in [20]. Safe storage terms for pectin-containing concentrate from Karina pumpkin pomace were determined by changes in pectin content. The pectin content was determined for 10 months at temperatures of $8{ }^{\circ} \mathrm{C}$ and $25^{\circ} \mathrm{C}$ with a control interval of once a month.

It is known that the pectin mass ratio gradually decreases during long-term storage of pectin-containing concentrates from pumpkin pomace at different temperatures. The $\mathrm{pH}$ of pectin concentrate will also have some effect.

To reduce the number of experiments and obtain a reliable assessment of the influence of the factors noted on pectin mass ratio, methods of multifactor experimental design were used.

Considering the nonlinear nature of the influence of storage temperature, time, and $\mathrm{pH}$ on pectin content, a three-factor composite uniform-rotatable experimental design was used for the mathematical description of this relationship [21, 22], consisting of 3 experimental blocks:

- a core of FFE design-23 of 8 experiments;

- a block containing star points (6 experiments);

- a block of parallel experiments in the center of experiments ( 6 experiments), ensuring the constant variance of the predicted values of the output criterion at all points of the studied region [21, 22].
Data processing and all necessary calculations were carried out using the algorithm [21] and the PLAN sequential regression analysis program described in detail in [23]. This program allows forming matrices of various experimental designs, calculating regression coefficients for the test criterion by the least squares method, determining necessary statistical characteristics of the obtained regression equation, including checking the heterogeneity of variances, determining the significance of regression coefficients, checking its adequacy to experimental data by the Fisher criterion.

Using the PLAN program, a second-order regression equation was obtained for the three studied factors $t, \tau$ and $\mathrm{pH}$ as follows:

$$
\begin{aligned}
& y=b_{0}+b_{1} x_{1}+b_{2} x_{2}+b_{3} x_{3}+b_{11} x_{1}^{2}+b_{22} x_{2}^{2}+ \\
& +b_{33} x^{3}+b_{12} x_{1} x_{2}+b_{13} x_{1} x_{3}+b_{23} x_{2} x_{3},
\end{aligned}
$$

where $y$ is the pectin mass ratio, $\% ; x_{1}$ is the coded value of pectin storage temperature $t ; x_{2}$ is the coded value of pectin storage time $\tau ; x_{3}$ is the coded value of pectin concentrate $\mathrm{pH}$.

The transition from natural to coded values of the indicated factors was carried out according to the following ratios:

$$
\begin{aligned}
& x_{1}=(t-15.5) / 5.05 ; \\
& x_{2}=(\tau-153.5) / 87.1 ; \\
& x_{3}=(\mathrm{pH}-5.6) / 0.9512,
\end{aligned}
$$

where $t$ is the pectin storage temperature, ${ }^{\circ} \mathrm{C}$; $\tau$ is the pectin storage time, days; $\mathrm{pH}$ is the pectin concentrate $\mathrm{pH}$.

In these ratios, the values of $15.5 ; 153.5$ and 5.6 are equal to the centers of experiments, respectively, in terms of pectin storage temperature, time and $\mathrm{pH}$. The variation intervals of the factors, as can be seen from the ratios (2), are equal for the pectin storage temperature of $5.05^{\circ} \mathrm{C}$, time of 87.1 days and for the concentrate $\mathrm{pH}$ of 0.9512 . The accepted values of the experimental centers and variation intervals provide necessary ranges for the studied factors, taking into account the axial distance: for the storage temperature $8 \ldots 25^{\circ} \mathrm{C}$, time $7 \ldots 300$ days and $\mathrm{pH} 4$ 4...7.2. This is more clearly shown in Table 1.

Table 1

Summary characteristics of the composite uniform-rotatable design for studying the relationship between pectin mass ratio and $t, \tau$ and $\mathrm{pH}$ factors

\begin{tabular}{|c|c|c|c|}
\hline Designations & \multicolumn{3}{|c|}{ Factors } \\
\hline Natural factor values & $t,{ }^{\circ} \mathrm{C}$ & $\tau$, days & $\mathrm{pH}$ \\
\hline Coded factor values & $x_{1}$ & $x_{2}$ & $x_{3}$ \\
\hline Factor variation intervals $\lambda$ & 5.05 & 87.1 & 0.9512 \\
\hline Factor levels: & & & \\
- lower star point $(-R)$ & 8 & 7 & 4 \\
- lower level & 11.45 & 66.4 & 4.9 \\
- center of experiment & 16.5 & 153.5 & 5.6 \\
- upper level & 24.55 & 240.6 & 6.55 \\
- upper star point $(+R)$ & 25 & 300 & 7.2 \\
\hline
\end{tabular}

The significance of the regression coefficients was checked by comparing them with the confidence interval $\varepsilon$ calculated by the expression

$$
\varepsilon=t_{c r} \sqrt{c_{i i}} s
$$


where $t_{c r}$ is the critical value of the Student's criterion; $c_{i i}$ is the diagonal element of the variance matrix [23].

The adequacy of the regression equation was checked by the Fisher criterion [21-23].

Using the obtained adequate regression equation in the MS Excel spreadsheet environment, response surfaces were constructed, giving a visual graphical representation of the influence of the studied factors and their paired interactions on the pectin mass ratio.

\section{Results of research on safe storage terms for the developed pectin-containing concentrates from pumpkin pomace}

\section{1. Production flow diagram for pectin concentrate from Karina pumpkin pomace}

Enzymatic hydrolysis of pectin-containing raw materials has a number of significant advantages over acid one traditionally used in pectin production. Firstly, there is no need to work with caustic, aggressive agents, the hydrolysis process occurs at a native $\mathrm{pH}$. Secondly, the requirements of labor protection are lower than with acid hydrolysis of raw materials. Thirdly, adjusting the enzyme dose and process conditions reduces the amount of by-products [24-27].

Based on the previously developed technological modes (water duty 1:10, extraction temperature $40-41{ }^{\circ} \mathrm{C}$, solution $\mathrm{pH} 6.0$, extraction time $4-5$ hours), a pectin-containing extract from pumpkin pomace with a pectin content of $0.85-1.05 \%$ was obtained. Extraction of pectin substances from Karina pumpkin pomace was carried out using the Pectinase from Aspergillus niger enzyme preparation (Fig. 1).

Production flow diagram for pectin concentrate (Fig. 1) consists of the following operations: raw material preparation; enzymatic extraction; filtration; centrifugation; enzyme inactivation; extract concentration; concentrate pasteurization; packing.

Preparation of pectin-containing raw materials consists in washing pumpkin with $25^{\circ} \mathrm{C}$ tap water cleaning (total losses are $3.32 \pm 1.0 \%$ )

Then, milling, liquid phase separation and obtaining of pomace from pumpkin fruit were carried out. The pomace was dried at $56{ }^{\circ} \mathrm{C}$ for 24 hours, followed by drying at room temperature of $20-22{ }^{\circ} \mathrm{C}$ until dry pumpkin pomace was obtained. The resulting dry pomace was milled, mixed with distilled water in a $1: 8$ ratio and left to swell at $48-50{ }^{\circ} \mathrm{C}$ for $12-15$ hours. Distilled water was again added to the resulting mixture to a 1:10 ratio and the $\mathrm{pH}$ of the medium was measured. To carry out enzymatic extraction, the Pectinase from Aspergillus niger enzyme preparation in an amount of $2 \%$ was added to the resulting mixture and extraction was carried out at $40-41{ }^{\circ} \mathrm{C}$ for $4-5$ hours. The samples were then stirred for 5 minutes every 30 minutes. After stirring, the extract was filtered, centrifuged, and the enzyme was inactivated for 30 minutes. The total pectin content in the pumpkin pomace extract ranged from 0.85 to $1.05 \%$, soluble solids $13.76 \pm 1.0 \%$. Freshly prepared pumpkin pomace after processing pumpkin fruits is unstable: enzymatic processes of protopectin decomposition during the day make it unsuitable for obtaining high-quality pectin. This implies the necessity and the exceptional importance of preserving raw materials. The pectin-containing pumpkin pomace extract was then concentrated by vacuum evaporation (at $t=58-60{ }^{\circ} \mathrm{C}$, pressure 0.5 $-0.7 \mathrm{~atm}$ ). The resulting pectin-containing concentrate was characterized by a soluble solids content of $24.0 \pm 0.02 \%$, total pectin content was about $2.50-2.60 \pm 0.02 \%$.

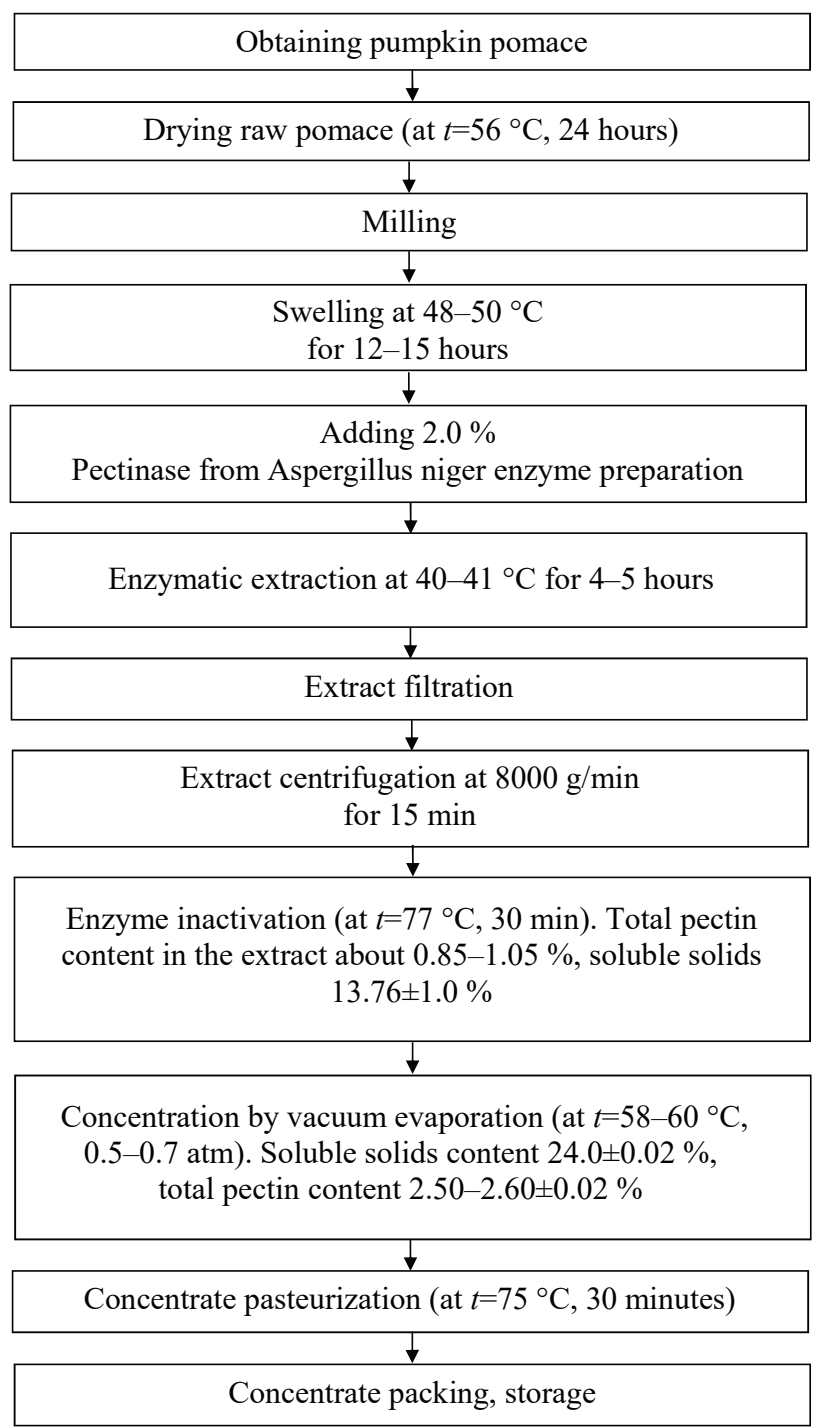

Fig. 1. Production flow diagram for Karina pumpkin pectin concentrate

The resulting product was pasteurized at $75^{\circ} \mathrm{C}$ for 30 minutes and packed in sterile containers.

5. 2. Determination of safe storage terms for pectin concentrate from Karina pumpkin pomace

The criterion for determining safe storage terms for the pectin-containing concentrate was a change in pectin amount. The pectin content was determined for 10 months at $8{ }^{\circ} \mathrm{C}$ and $25^{\circ} \mathrm{C}$ with a control interval of once a month. A decrease in pectin content in the concentrate by more than $25.0 \%$ will be considered the end of the shelf life of the studied products.

The results of experimental determination of storage time of the pectin-containing concentrate obtained from Karina pumpkin pomace at temperatures of $8{ }^{\circ} \mathrm{C}$ and $25^{\circ} \mathrm{C}$ by pectin content are presented in Table 2 . 
Table 2

Effect of storage temperature and time of pumpkin pomace pectin concentrate on pectin content

\begin{tabular}{|c|c|c|c|c|c|c|c|c|c|c|c|c|}
\hline \multirow{2}{*}{ Indicator } & \multirow{2}{*}{ Control } & \multicolumn{10}{c|}{ Research months } \\
\cline { 3 - 10 } & 01 & 02 & 03 & 04 & 05 & 06 & 07 & 08 & 09 & 10 \\
\hline \multicolumn{10}{|c|}{ Changes at storage temperature, $8{ }^{\circ} \mathrm{C}$} \\
\hline $\begin{array}{c}\text { Pectin } \\
\text { content, } \%\end{array}$ & $2.41 \pm 0.01$ & $2.41 \pm 0.02$ & $2.41 \pm 0.01$ & $2.40 \pm 0.02$ & $2.40 \pm 0.01$ & $2.37 \pm 0.02$ & $2.37 \pm 0.02$ & $2.35 \pm 0.01$ & $2.35 \pm 0.02$ & $2.32 \pm 0.01$ & $2.11 \pm 0.01$ \\
\hline \multicolumn{10}{|c|}{ Changes at storage temperature, $25^{\circ} \mathrm{C}$} \\
\hline $\begin{array}{c}\text { Pectin } \\
\text { content, \% }\end{array}$ & $2.41 \pm 0.01$ & $2.41 \pm 0.02$ & $2.40 \pm 01$ & $2.22 \pm 0.02$ & $2.39 \pm 0.01$ & $2.35 \pm 0.02$ & $2.32 \pm 0.01$ & $1.98 \pm 0.02$ & $1.27 \pm 0.02$ & $1.09 \pm 0.02$ & $0.88 \pm 0.02$ \\
\hline
\end{tabular}

As a result of research (Table 2), it was found that during storage of pectin concentrate from Karina pumpkin pomace, the pectin content in the concentrate decreased compared to the control sample. During storage at $8{ }^{\circ} \mathrm{C}$ for 10 months, the pectin content decreased by $0-12.45 \%$, at $25{ }^{\circ} \mathrm{C}-$ by $0-63 \%$.

Processing of the obtained data by the least squares method provided an interpolation equation describing the relationship between pectin content in the concentrate and storage time and temperature

$$
\begin{aligned}
& y=2.072-0.2070 \tau+0.01695 t- \\
& -0.007861 \tau t-0.01639 \tau^{2}, s=0.026 \%,
\end{aligned}
$$

where $y$ is the pectin content, $\%$; $\tau$ is the pectin concentrate storage time, months; $t$ is the storage temperature, ${ }^{\circ} \mathrm{C} ; s$ is the standard deviation, $\%$.

Based on equation (4), graphical relationships for pectin content during storage at different temperatures were constructed, shown in Fig. 2.

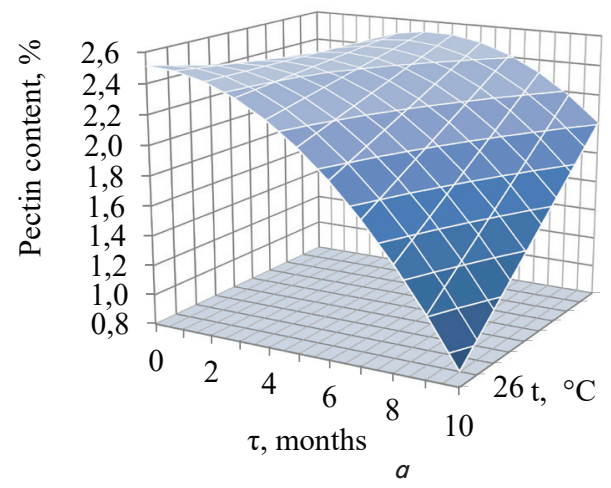

$2,4-2,6$

$=2,2-2,4$

$\llbracket 2,0-2,2$

$=1,8-2,0$

$=1,6-1,8$

$\because 1,4-1,6$

$\because 1,2-1,4$

- $1,0-1,2$

- $0,8-1,0$

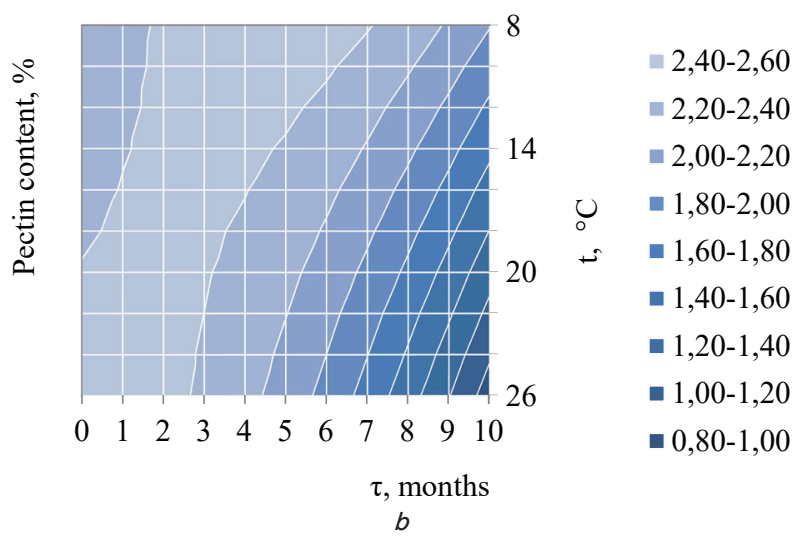

Fig. 2 The analysis of the graphic data in shows that the safe storage period for Karina pumpkin pomace concentrates at a temperature of $25^{\circ} \mathrm{C}$ is 7 months, at $8{ }^{\circ} \mathrm{C}-10$ months. The research results meet the standard requirements for these products
5. 3. Modeling of the mutual influence of pumpkin pectin concentrate storage conditions by pectin mass ratio

The use of pectin substances as natural detoxicants for people living in adverse environmental conditions requires further research to preserve these substances in products and further use [28, 29].

To compile a mathematical description of changes in the pectin mass ratio with different $\mathrm{pH}$ during storage under different temperature conditions, an active multifactorial experiment was conducted. The results are shown in Table 3.

Table 3

Matrix and results of experiments to determine the

\begin{tabular}{|c|c|c|c|c|c|c|c|c|}
\hline \multirow{3}{*}{$\begin{array}{c}\text { Experimental } \\
\text { number }\end{array}$} & \multicolumn{6}{|c|}{ Experimental conditions } & \multirow{2}{*}{\multicolumn{2}{|c|}{$\begin{array}{c}\text { Experimenta } \\
\text { results, } \%\end{array}$}} \\
\hline & \multicolumn{3}{|c|}{ coded variables } & \multicolumn{3}{|c|}{$\begin{array}{c}\text { natural vari- } \\
\text { ables }\end{array}$} & & \\
\hline & $x_{1}$ & $x_{2}$ & $x_{3}$ & $t,{ }^{\circ} \mathrm{C}$ & $\begin{array}{c}\tau, \\
\text { days }\end{array}$ & $\mathrm{pH}$ & $Y_{\exp }$ & $Y_{\text {est }}$ \\
\hline 1 & -1 & -1 & -1 & 11.4 & 66,4 & 4.9 & 2.60 & 2.61 \\
\hline 2 & 1 & -1 & -1 & 24.5 & 66.4 & 4.9 & 2.25 & 2.31 \\
\hline 3 & -1 & 1 & -1 & 11.4 & 240.0 & 4.9 & 2.35 & 2.38 \\
\hline 4 & 1 & 1 & -1 & 24.5 & 240.0 & 4.9 & 1.43 & 1.51 \\
\hline 5 & -1 & -1 & 1 & 11.4 & 66.4 & 6.6 & 2.55 & 2.54 \\
\hline 6 & 1 & -1 & 1 & 24.5 & 66.4 & 6.6 & 2.35 & 2.38 \\
\hline 7 & -1 & 1 & 1 & 11.4 & 240.0 & 6.6 & 2.27 & 2.31 \\
\hline 8 & 1 & 1 & 1 & 24.5 & 240.0 & 6.6 & 1.50 & 1.58 \\
\hline 9 & -1.682 & 0 & 0 & 8.0 & 53.5 & 5.6 & 2.47 & 2.47 \\
\hline 10 & 1.682 & 0 & 0 & 25.0 & 153.5 & 5.6 & 1.71 & 1.60 \\
\hline 11 & 0 & \begin{tabular}{|l|}
-1.682 \\
\end{tabular} & 0 & 15.5 & 7.0 & 5.6 & 2.56 & 2.54 \\
\hline 12 & 0 & 1.682 & 0 & 15.5 & 300.0 & 5.6 & 1.77 & 1.68 \\
\hline 13 & 0 & 0 & -1.682 & 15.5 & 153.5 & 4.0 & 2.60 & 2.50 \\
\hline 14 & 0 & 0 & 1.682 & 15.5 & 153.5 & 7.2 & 2.50 & 2.50 \\
\hline 15 & 0 & 0 & 0 & 15.5 & 153.5 & 5.6 & 2.42 & 2.42 \\
\hline 16 & 0 & 0 & 0 & 15.5 & 153.5 & 5.6 & 2.39 & 2.42 \\
\hline 17 & 0 & 0 & 0 & 15.5 & 153.5 & 5.6 & 2.37 & 2.42 \\
\hline 18 & 0 & 0 & 0 & 15.5 & 153.5 & 5.6 & 2.45 & 2.42 \\
\hline 19 & 0 & 0 & 0 & 15.5 & 153.5 & 5.6 & 2.47 & 2.42 \\
\hline 20 & 0 & 0 & 0 & 15.5 & 153.5 & 5.6 & 2.41 & 2.42 \\
\hline
\end{tabular}
dependence of pectin mass ratio on the studied factors

By processing the experimental data, the following regression equation in coded variables is obtained

$$
\begin{aligned}
& y=2.42145-0.25760 x_{1}-0.25836 x_{2}-0.13647 x_{1}^{2}- \\
& -0.10996 x_{2}^{2}+0.02613 x_{3}^{2}-0.1425 x_{1} x_{2}+0.03750 x_{1} x_{3} .
\end{aligned}
$$


The equation according to the Fisher criterion adequately describes the experimental data, since the following condition is met

$$
F_{r}=4.40 \leq F_{c r}(0.95 ; 4 ; 5)=4.70 \text {. }
$$

Given the presence of significant linear, quadratic regression coefficients and coefficients of paired interactions of individual factors for pectin mass ratio, it is quite difficult to conduct an analytical analysis of the equation. This requires the transformation of equation (5) into several quasi-single-factor bulky equations [21]. The influence of the factors is much easier to see on the graphical interpretation of the regression equation (Fig. 3).

Therefore, to visualize the influence of both individual factors and their joint effect, response surfaces were constructed on the basis of equation (5) for the significant coefficients of paired interactions $x_{1} x_{2}$ and $x_{1} x_{3}$, shown in Fig. 3. At the same time, the values of the third factors were fixed at the levels giving the maximum estimated values of pectin mass ratios.

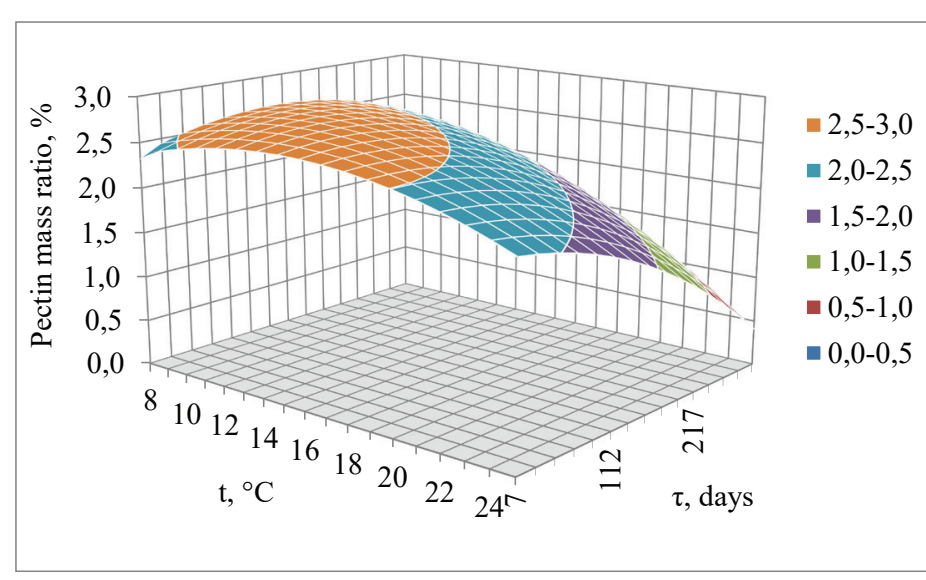

$a$

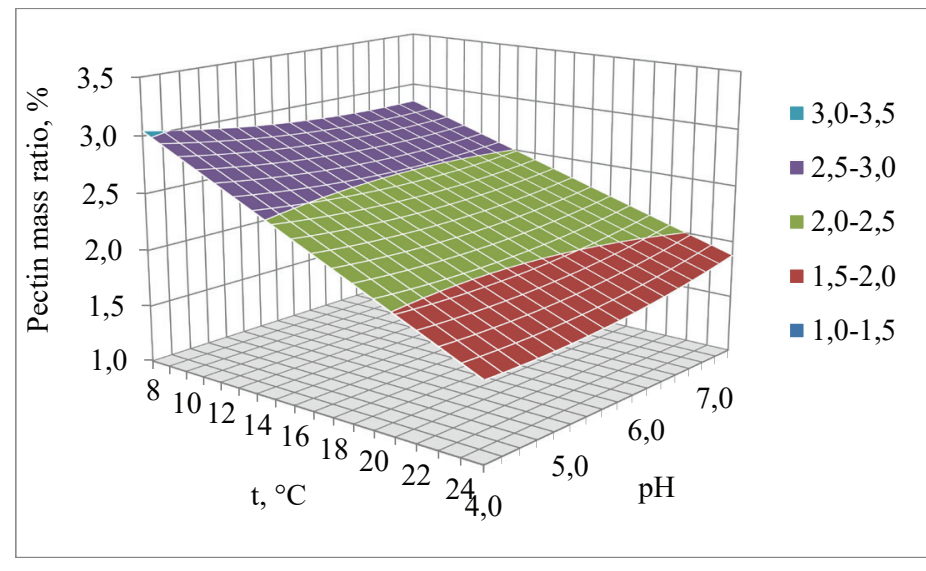

$b$

Fig. 3. Response surfaces of the dependence of the pectin content on the concentrate storage temperature and time: $a-\mathrm{pH}=7.2$; $b-\tau=207.6$ day

\section{Discussion of the results of research on safe storage terms for pumpkin pectin concentrate}

The literature review shows that pectin substances have the ability to bind and remove stable and radioactive metals from the human body. At the same time, low-esterified pectin substances, including the obtained pumpkin pectin, have the best complexing properties.

The conducted scientific research allowed us to substantiate the sequence and parameters of pectin concentrate production from Karina pumpkin pomace. The flow diagram consists of the following operations: preparation of pectin-containing raw materials; enzymatic extraction; extract filtration; centrifugation; enzyme inactivation; extract concentration; concentrate pasteurization; packing. To carry out enzymatic extraction, the Pectinase from Aspergillus niger enzyme preparation in an amount of $2 \%$ was used. The total pectin content in the pumpkin pomace extract ranged from 0.85 to $1.05 \%$, soluble solids $13.76 \pm 1.0 \%$. The soluble solids content in the pectin concentrate was $24.0 \pm 0.02 \%$, total pectin content was about $2.50-2.60 \pm 0.02 \%$.

Safe storage terms for pectin-containing concentrate from Karina pumpkin pomace were determined on the basis of changes in pectin amount. The pectin content was determined for 10 months at temperatures of $8{ }^{\circ} \mathrm{C}$ and $25^{\circ} \mathrm{C}$ with a control interval of once a month. As a result of research, it was found that during storage of pectin concentrate from Karina pumpkin pomace, the pectin content in the concentrate decreased compared to the control sample. During storage at a temperature of $8{ }^{\circ} \mathrm{C}$ for 10 months, the pectin content decreased by $0-12.45 \%$, at $25^{\circ} \mathrm{C}-$ by $0-63 \%$.

Based on the results, it can be concluded that the safe storage period for pectin-containing concentrates of Karina pumpkin extracts at a temperature of $25^{\circ} \mathrm{C}$ is 7 months, at $8{ }^{\circ} \mathrm{C}-10$ months and more. The research results meet the standard requirements for these products.

An important condition for using pectin concentrates is the determination of shelf life for safe consumption. On this basis, in order to determine rational storage parameters and periods for the pumpkin concentrate, experiments are planned to determine the influence of storage temperature, $\mathrm{pH}$ and time on pectin amount in the pumpkin concentrate.

The experimental determination of safe storage terms of the concentrate, the results of which are given in Table 2, equation (4) and Fig. 2, provided the following.

Analysis of the obtained equation (4) shows that the pectin mass ratio has a linear relationship with the storage temperature of pectin concentrate, which is complicated by the combined effect of storage time (see negative coefficient of paired interaction). The storage time of the concentrate reduces the pectin content by quadratic law.

The combined effect of time and temperature on pectin content is more clearly shown in Fig. 2. It can be seen that at the beginning of pectin concentrate storage, the change in concentrate storage temperature slightly affects the pectin mass ratio. However, with an increase in storage time, the pectin mass ratio decreases by quadratic law, and with an increase in temperature, a rapid decrease in pectin is observed after 10 months of storage at a temperature of $25^{\circ} \mathrm{C}$.

Mathematical modeling of the mutual influence of storage conditions of pumpkin pectin concentrate with different 
$\mathrm{pH}$ in terms of pectin mass ratio, the results of which are given in Table 3, equation (5) and Fig. 3 showed the following.

Fig. 3, $a$ shows that the relationship of pectin mass ratio with $t$ and $\tau$ is quadratic, representing a convex surface with a maximum. With an increase in pectin storage temperature and time, a decrease in the pectin mass ratio is observed. So, at a temperature of $8{ }^{\circ} \mathrm{C}$, an increase in the concentrate storage time from 7 to 300 days practically does not lead to a decrease in pectin. However, storage at $25^{\circ} \mathrm{C}$ leads to a significant decrease in pectin mass ratio from initial $2.41 \%$ to $0.42 \%$, i. e. 5.7 times.

Fig. $3, b$ shows that an increase in pectin storage temperature leads to a linear decrease in pectin mass ratio at a rate of $0.174 \%$ per one degree of temperature change. When the $\mathrm{pH}$ value changes, the safe storage terms for the concentrate practically do not change, as indicated by significantly lower regression coefficients at $\mathrm{pH}$. So, during the concentrate storage at $20{ }^{\circ} \mathrm{C}$ for 300 days, the pectin mass ratio is within $2.07 \ldots 2.16 \%$.

For the known storage temperature and $\mathrm{pH}$ of the concentrate, from equation (5), appropriate storage time can be determined, at which the residual pectin mass ratio will be at least $25 \%$ of the original value, i. e. not lower than $1.81 \%$. So, during storage of pectin concentrate with $\mathrm{pH}=7.2$ at $20^{\circ} \mathrm{C}$, the safe storage time will be 230 days.

This study was conducted under a temperature from 8 to $25^{\circ} \mathrm{C}$ with storage time of up to 300 days. Research is needed the results of which may be the use of various pre- servatives increasing safe storage terms of pectin concentrates while maintaining the original amount and quality of pectin.

\section{Conclusions}

1. A flow diagram for the production of pectin concentrate from Karina pumpkin pomace has been developed. The total pectin content in the pumpkin pomace extract ranged from 0.85 to $1.05 \%$, soluble solids $13.76 \pm 1.0 \%$. The resulting pectin-containing concentrate was characterized by a soluble solids content of $24.0 \pm 0.02 \%$, the total pectin content was about $2.50-2.60 \pm 0.02 \%$.

2 . Based on the study of pectin content, it was found that the safe storage period of the pectin concentrate from Karina pumpkin extracts at a temperature of $25^{\circ} \mathrm{C}$ is 7 months, at $8{ }^{\circ} \mathrm{C}-10$ months.

3. It was found that the relationship of pectin mass ratio with $t$ and $\tau$ is quadratic, representing a convex surface with a maximum. With an increase in pectin storage temperature and time, a decrease in the pectin mass ratio is observed. It is shown that at a temperature of $8{ }^{\circ} \mathrm{C}$, an increase in the concentrate storage time from 7 to 300 days practically does not lead to a decrease in pectin. However, storage at $25^{\circ} \mathrm{C}$ leads to a significant decrease in pectin mass ratio from initial $2.41 \%$ to $0.42 \%$, i. e. 5.7 times.

\section{References}

1. Zhexenbay, N., Akhmetsadykova, S., Nabiyeva, Z., Kizatova, M., Iskakova, G. (2020). Using pectin as heavy metals detoxification agent to reduce environmental contamination and health risks. Procedia Environmental Science, Engineering and Management, 7 (4), 551-562.

2. Rascón-Chu, A., Díaz-Baca, J. A., Carvajal-Millán, E., López-Franco, Y., Lizardi-Mendoza, J.; Thakur, V. K., Thakur, M. K. (Eds.) (2016). New Use for an "Old” Polysaccharide: Pectin-Based Composite Materials. Handbook of Sustainable Polymers: Structure and Chemistry. Singapore: Pan Stanford Publishing Pte. Ltd., 72-107.

3. Lara-Espinoza, C., Carvajal-Millán, E., Balandrán-Quintana, R., López-Franco, Y., Rascón-Chu, A. (2018). Pectin and Pectin-Based Composite Materials: Beyond Food Texture. Molecules, 23 (4), 942. doi: http://doi.org/10.3390/molecules23040942

4. Bray, J. K., Chiu, G. S., McNeil, L. K., Moon, M. L., Wall, R., Towers, A. E., Freund, G. G. (2018). Switching from a highfat cellulose diet to a high-fat pectin diet reverses certain obesity-related morbidities. Nutrition \& Metabolism, 15 (1). doi: http://doi.org/10.1186/s12986-018-0294-7

5. Chen, Q., Zhu, L., Tang, Y., Zhao, Z., Yi, T., Chen, H. (2017). Preparation-related structural diversity and medical potential in the treatment of diabetes mellitus with ginseng pectins. Annals of the New York Academy of Sciences, 1401 (1), 75-89. doi: http://doi.org/10.1111/nyas.13424

6. Khotimchenko, M., Makarova, K., Khozhaenko, E., Kovalev, V. (2017). Lead-binding capacity of calcium pectates with different molecular weight. International Journal of Biological Macromolecules, 97, 526-535. doi: http://doi.org/10.1016/j.ijbiomac.2017.01.065

7. Kizatova, M. Z., Azimova, S. T., Iskakova, G. K., Makhmudov, F. A., Bekturganova, A. A. (2020). The introduction of pectincontaining foods for the competitiveness of enterprises. Entrepreneurship and Sustainability Issues, 7 (4), 3191-3199. doi: http://doi.org/10.9770/jesi.2020.7.4(40)

8. Ramachandran, C., Wilk, B. J., Hotchkiss, A., Chau, H., Eliaz, I., Melnick, S. J. (2011). Activation of Human T-Helper/Inducer Cell, T-Cytotoxic Cell, B-Cell, and Natural Killer (NK)-Cells and induction of Natural Killer Cell Activity against K562 Chronic Myeloid Leukemia Cells with Modified Citrus Pectin. BMC Complementary and Alternative Medicine, 11 (1). doi: http://doi.org/10.1186/1472-6882-11-59

9. Nikitina, V. S., Abdullin, M. I., Gaynanova, L. T. (2012). Poluchenie pektinov, flavanoidov i karotinoidov iz korney lekarstvennykh rasteniy. Vestnik Bashkirskogo universiteta, 4, 1715-1720.

10. Tipsina, N. N., Tipsin, E. A., Batura, N. G. (2014). Pektiny iz khvoynykh porod derevev. Perspektivy ikh ispolzovaniya v pischevoy promyshlennosti. Vestnik KrasGAU, 12, 231-233.

11. Tunekova, Yu. A., Mukhametshina, Yu. A., Shmakova, Yu. A. (2012). Issledovanie effektivnosti biopolimernykh sorbentov na osnove pektina dlya vyvedeniya izbytochnogo soderzhaniya metallov iz organizma. Khimiya, tekhnologiya i ispolzovanie polimerov, 4, 71-73.

12. Niture, S. K. (2013). Plant pectin: a potential source for cancer suppression. American Journal of Pharmacology and Toxicology, 8 (1), 9-19. doi: http://doi.org/10.3844/ajptsp.2013.9.19 
13. Eliaz, I., Hotchkiss, A. T., Fishman, M. L., Rode, D. (2006). The effect of modified citrus pectin on urinary excretion of toxic elements. Phytotherapy Research, 20 (10), 859-864. doi: http://doi.org/10.1002/ptr.1953

14. Zhao, Z. Y., Liang, L., Fan, X., Hotchkiss, A. T., Wilk, B. J., Eliaz, I. (2008). The role of modified citrus pectin as the effective chelator of lead in children hospitalized with toxoc lead levels. Altern Their Health Med, 14 (4), 34-38.

15. Khasina, E. I., Tiupeleev, P. A., Sgrebneva, M. N. (2004). Gastroprotective effect of zosterin, a pectin from seagrass ZOSTERA MARINA L. Oriental Pharmacy and Experimental Medicine, 4 (4), 253-260. doi: http://doi.org/10.3742/opem.2004.4.4.253

16. Gelgay, M. K., Donchenko, L. V., Reshetnyak, A. I. (2008). Innovative technology of pectin from secondary sources of raw material after processing coffee. New Technologies, 6, 15-18.

17. Kizatova, M. Zh., Iskakova, G. K., Nabieva, Zh. S., Azimova, S. T., Ustenova, G. O., Kozhanova, K. K. (2020). Pektiny: osnovnye svoystva, tekhnologii, primenenie. Almaty: IP $\ll$ Miras», 265.

18. Morris, G. A., Castile, J., Smith, A., Adams, G. G., Harding, S. E. (2010). The effect of different storage temperatures on the physical properties of pectin solutions and gels. Polymer Degradation and Stability, 95 (12), 2670-2673. doi: http://doi.org/10.1016/j.polymdegradstab.2010.07.013

19. Padival, R. A., Ranganna, S., Manjrekar, S. P. (1981). Stability of pectins during storage. International Journal of Food Science \& Technology, 16 (4), 367-378. doi: http://doi.org/10.1111/j.1365-2621.1981.tb01829.x

20. DList, D., Buddrub, S., Bodtke, M. (1985). Pectinbestimmung mit meta-Phenylphenol. Zeitschrift Fur Lebensmittel-Untersuchung Und -Forschung, 180 (1), 48-52. doi: http://doi.org/10.1007/bf01042912

21. Voznesenskiy, V. A. (1981). Statisticheskie metody planirovaniya eesperimenta $\mathrm{v}$ tekhniko-ekonomicheskikh issledovaniyakh. Moscow: Finansy i statistika, 263.

22. Khartman, K., Letskiy, E., Shefer, V. (1977). Planirovanie eksperimenta v issledovanii tekhnologicheskikh protsessov. Moscow: Mir, 555.

23. Stankevich, G. N. (1992). Sostavlenie matematicheskogo opisaniya po eksperimentalnym dannym. Matematicheskoe modelirovanie protsessov pischevykh proizvodstv. Kiyv: Vischa shkola, 3-59.

24. Sandri, I., Silveira, M. (2018). Production and Application of Pectinases from Aspergillus niger Obtained in Solid State Cultivation. Beverages, 4 (3), 48. doi: http://doi.org/10.3390/beverages4030048

25. Kizatova, M. Zh., Iskakova, G. K., Azimova, S. T., Nabieva, J. S., Alibaeva, B. N. (2020). Establishment of mode parameters of extraction of pumpkin pectin-containing extract by enzyme method. Eurasia J Biosci, 14, 4261-4269.

26. Oyeleke, S., Oyewole, O., Egwim, E., Dauda, B., Ibeh, E. (2012). Cellulase and Pectinase Production Potentials of Aspergillus Niger Isolated from Corn Cob. Bayero Journal of Pure and Applied Sciences, 5 (1). doi: http://doi.org/10.4314/bajopas.v5i1.15

27. Yuan, Y., Zhang, X.-Y., Zhao, Y., Zhang, H., Zhou, Y.-F., Gao, J. (2019). A Novel PL9 Pectate Lyase from Paenibacillus polymyxa KF-1: Cloning, Expression, and Its Application in Pectin Degradation. International Journal of Molecular Sciences, 20 (12), 3060. doi: http://doi.org/10.3390/ijms20123060

28. Nawirska, A., Kwaśniewska, M. (2005). Dietary fibre fractions from fruit and vegetable processing waste. Food Chemistry, 91 (2), 221-225. doi: http://doi.org/10.1016/j.foodchem.2003.10.005

29. Maxwell, E. G., Belshaw, N. J., Waldron, K. W., Morris, V. J. (2012). Pectin - An emerging new bioactive food polysaccharide. Trends in Food Science \& Technology, 24 (2), 64-73. doi: http://doi.org/10.1016/j.tifs.2011.11.002 